\title{
5. Fragments from a Fiji coup diary
}

\section{ABSIRACI}

Fiji has endured four coups in the past 22 years. On 10 April 2009, President Ratu Josefa Iloilo suspended the Constitution, sacked the judiciary, postponed any general election until 2014 and appointed himself as head of state. He reinstated 2006 coup leader Commodore Voreqe Bainimarama as interim Prime Minister, who in turn reappointed his cabinet in defiance of international condemnation. A censorship crackdown on the media and civil society followed. The author is a media educator and journalist who worked for a total of 11 years at the University of the South Pacific, including experiencing both the 2000 and the 2006 coups. He later returned to Fiji as social media educator for the National Council for Building a Better Fiji (NCBBF). The Council was critical of the media during the period it developed a draft of the People's Charter. It recommended changes to the law to establish a Media Tribunal, which was also planned to encourage qualified local personnel for editorial, subeditorial and publisher positions; provide a wide diversity of local programmes for television media and develop community radio and community television through a media tax. While the People's Charter was seen as a necessary and constructive contribution to the future of Fiji, the leadership of Bainimarama was questioned after the repeal of the constitution. This article, opening with the author's open letter to Bainimarama after the Easter putsch, offers reflections from a coup diary.

\section{PATRICK CRADDOCK}

Media educator, New Zealand

AN open letter to the interim regime leader of the Republic of Fiji:

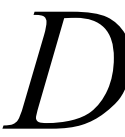

ear Commodore Voreqe Bainimarama,

So-only good news can be reported. Wow-perhaps the army can try and shut down Al Jazeera, BBC and CNN too? I notice their reporting doesn't praise the army for their actions. 
Fiji journalists must be finding it hard to discover what good news there is to report on the army?

Commodore, your actions this week have surely given a new lease of life to Fiji blog sites. For us in New Zealand-and Oz and elsewhere-where else should we now look for news on Fiji, but through the blogs? I read tonight on a blog site that the army is taking petrol from gas stations without payment-true or untrue? How am I to assess the truth of this comment-not from the Fiji newspapers, surely? They won't be allowed to print that type of bad news, even if it is true?

So... a wait until possibly 2014 before the citizens of Fiji can vote for the government they want? Most governments voted by the people, would not get that lease of life with long term promises to improve the lives of their citizens. From 2006 until 2014 is eight years... a long time for a visionary leader to prepare policies of political change. Too bloody long.

It's surely time for citizens (and those who wear army uniform too) to tell you, Commodore, about the real world of politics.

Last year, the now defunct National Council for Building a Better Fiji $(N C B B F)$ initiated by you, put together a draft of a People's Charter. More than 200 citizens from all over Fiji helped to draft the 'pillars' that defined the content of the charter.

John Samy, of the NCBBF Secretariat, worked through these ideas and put together a draft charter. The secretariat then set about spreading the ideas among the public for them to comment upon.

The work involved printing and distributing between nearly 200,000 of copies of the draft People's Charter in the three main languages; setting up $T V$ interviews and approving a radio campaign of over 100 mini-programmes and adverts on the draft charter content. I know about the radio side as I put the radio programmes together. Some of them were repeated more than five times a day for several months on English, Hindi and Fijian-language radio stations.

It may be useful for you, Commodore, to look again at the draft of the People's Charter - especially Pillar Eight. My draft copy says that the 'way forward' includes reducing the incidence of poverty by 50 percent by 2015. Nearly 200,000 of your people live in squatter camps.

If the scenario of a democratic election does not take place in 2014, a new government will take one look at this worthy pillar and say... it was your 
responsibility Commodore-you were in total control of Fiji since 2006! There will also be serious questions to ask the President, but will he be around to answer and give his point of view? He is an old and frail man.

Commodore-you chose to be a politician. You will be judged by the people of Fiji on your achievements, ie. providing jobs, housing, health care and education, and not by rhetoric and your ability to dance around kicking the constitution and journalists.

I'm from New Zealand, we have a democracy-it is flawed - all democracies are. But our politicians are judged and returned or replaced by us-even if it is only once every three years. Helen Clark was voted out and left quietly, if John Key loses the next election, he too will bow out with grace. Democracy is far from a perfect system. But even giving you credit for doing what you did with the best of intentions, you may well end up in your old age looking back and seeing that the forthcoming 2014 elections did not solve the serious problems of Fiji.

And, in case I forget, the Fiji media will report that news in great detail!

You kicked out the Constitution; why not just pass a decree changing the voting system and putting the draft of the People's Charter into law? All it needs now is a stroke of the pen-or ink on the muzzle of your gun. You could do the task in five minutes.

\section{Patrick Craddock}

Greytown

PS. - I wrote this letter as I recalled my meetings with many members of the working parties who prepared the ideas behind the draft of the People's Charter. Most of these dedicated individuals I talked with disapproved of the way the army had taken over the country, but they were prepared to give Bainimarama a chance to do what he said he would do-which in essence was to rid their country of racial policies, corruption and give people a better standard of living. I think now how many of them are wondering if Bainimarama is the leader they all wanted him to be? (Craddock, 2009) 


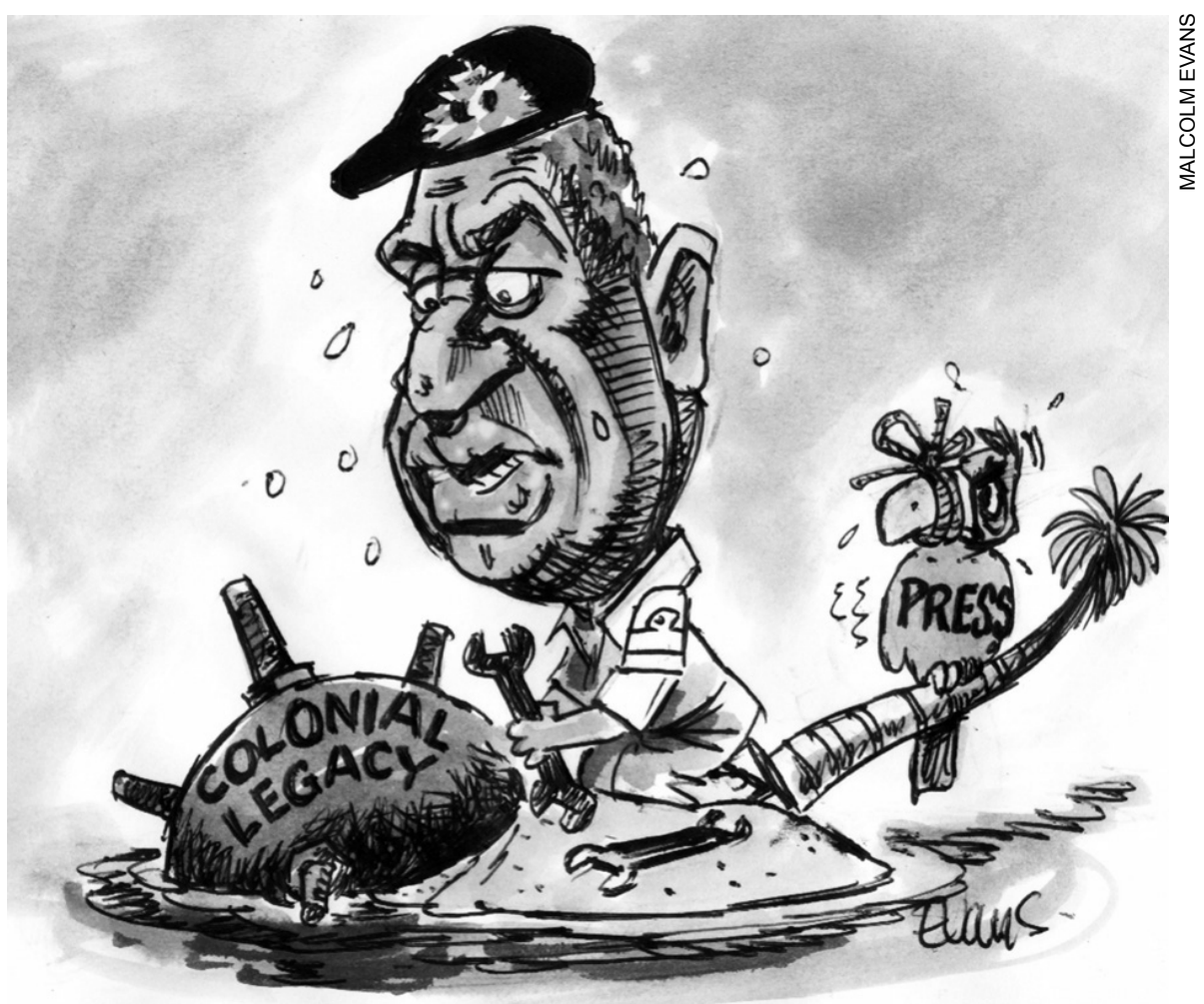

\section{Diary entries}

December 5, 2006, 6 pm:

Completed the last journalism tutorial for the day at the university, rushed home and turned on the TV news. Commodore Bainimarama has just declared a state of emergency and made himself inter-alia President of Fiji. He dismissed the Prime Minister, Laisenia Qarase and appointed Dr Jona Baravilala Senilagakali, a military doctor and retired public servant, as interim prime minister. Petty crime shows signs of escalating.

\section{December 6:}

A bad time for some. Burglaries, house invasions and attacks on people continue. Two days after the coup the woman I employ as a housekeeper, who lives in a squatter area, is pushed to the ground while walking down a street with her brother-in-law. He got punched around the face and they were 
both kicked. Their small amount of money for food is stolen plus her small thin gold necklace.

The army promises to restore law and order. Today they are all over Suva. Soldiers with guns are in the streets manning barriers and conducting searches.

Soldiers go to the newsrooms of the mainstream media. The following day, both The Fiji Times and Fiji Television decide not to publish news for one day. After discussions between the Fiji Media Council and media management teams, the military withdraw.

Journalism students start writing stories on this, the fourth coup since 1987, which looks like it will be going on for a long time. Simple rules of personal safety for the students are established. At all times two students are to go together to any military interview; advise the lecturer and a colleague on their time of departure and expected time of return from the interview; first year students to be discouraged from seeking interviews with the military.

Many university students are scared and want to go home to Tonga, Solomon Islands, Samoa, Kiribati or wherever they live. A few have left—or do not attend classes.

\section{December 6-30:}

Bad news for Laisenia Qarase, the elected and legal Fiji Prime Minister. $\mathrm{He}$ is ousted, along with all his government. Escorted from his house and his car taken. There are guns everywhere. All seen on TV. Bainimarama is sacking a number of senior public servants including the Commissioner of Police, Andrew Hughes, who was in Australia at the time, and Acting Police Commissioner, Moses Driver. Around half of the chief executive officers in the Public Service are served with termination letters.

The army coup leader accuses the Qarase-led government of introducing legislation for the benefit of some of its supporters and cronies.

Our aim, says the army chief, is to 'steer our beloved nation into peace, stability, a just solution and to preserve our Constitution'. It is being justified under the 'doctrine of necessity', which under English common law is seen as a justification for a citizen to break the law if there is an overwhelming urgency.

The way I see it, the argument is strictly between Qarase and Bainimarama. Both men wanting to destroy the power of the other. Both went to 
New Zealand under an invitation from then New Zealand Prime Minister Helen Clark, and talked, but their enmity was too great. The meeting failed to achieve positive results. Earlier there had been tensions between the army commander and the Prime Minister. Bainimarama accused Qarase of wanting to weaken the army by endeavoring to remove him from his post.

It has been his aim from day one. If he succeeds there will be no one to monitor them, and imagine how corrupt it is going to be. If civil servants speak out against the government, they are sacked. If the provincial councils speak, their allocated funds are reduced, so we are the only hope of the silent majority. (Lal, 2007a)

And Bainimarama had other support for his views that the Qarase government was not working for the interests of the people. The Citizens Constitutional Forum (CCF) was already on record with its criticism of the Qarase regime. On 4 December 2006 just before the coup took place the CCF sent out a mixed message saying that a coup would be illegal but the Qarase government had a track record of six years of illegal activities. It looked to an observer from the outside as if there was considerable support for the army. Is Bainimarama to be, as one university academic questioned over a drink, the Kemal Ataturk of the Pacific by being first a soldier and then a statesman?

Not so, according to outspoken pro-democracy activist Laisa Digitaki, who was beaten and forced to run through the capital at gunpoint with five others. The Fiji Sun newspaper of December 27 publishes a photograph of Digitaki wearing a neck brace and sitting in a wheelchair at the Suva Private Hospital. She says she fears further assault by the military but will not elaborate on her ordeal (Rina, 2006).

The same newspaper reports soldiers visiting the home of Laisa Vulakoro, a singer, and asked her to stop expressing opinions about the commander or suffer the same fate as pro-democracy supporters. Ms Vulakoro refused to be deterred by the army visit and says, 'They were polite and just came to warn me. But I would like to highlight here that I have done nothing wrong-merely expressed my views on what is happening in Fiji.' (Rika, 2006). 


\section{January 4, 2007:}

The Army Commander, Bainimarama, gives back the President, Ratu Josefa Iloilo, his powers, but gets himself appointed as Prime Minister. Ratu Josefa thanks the Army Commander for having the courage to step in and take control of the country and notes that 'decisive decisions needed to be made'. When the coup occurred, the President said in a statement that he neither condoned nor condemned the coup (Lal, 2007b).

\section{January 6:}

There was little surprise shown by some observers when the latest coup happened, Dr Steven Ratuva, an academic at USP, noted in a talk he gave today.

Of all the coups in the world I have studied, the 2006 Fiji coup was probably one of the most unusual as it defied all the conventions of a 'classical' military coup where everything was based on secrecy, surprise and speed (the 'triple S'). The 2006 coup was not based on any of these - secrecy, surprise or speed.

It was a gradual and well-publicised process taking months, weeks and days. It was the culmination of differences between the government and the military which provoked demands for reform by the military, leading to threats and finally warning of a takeover before the actual assumption of executive authority. It was very open and public. (Ratuva, 2007)

\section{January 30:}

First information about an alleged beating by the army on a 19-year-old man Sakiusa Rabaka, who undergoes surgery.

\section{February 20:}

Commodore Bainimarama gives a speech at the Queen Elizabeth Military Barracks. Talks on the 'roadmap' to parliamentary democracy. He says: 'Fiji will be ready for a general election and full restoration of parliamentary democracy as early as 2010.' So we have a shift of time here from the original proposal of March 2009.

\section{February 26:}

Sakiusa dead. Mother mourns and goes public that her son was picked up by 
six soldiers, taken to the Black Rock Reservoir, told to strip naked, made to carry sacks of sand and beaten up.

\section{April 18-25:}

There is a growth of a number of new blogsites that encourage free expression about the coup, its effects and comments on some of the people behind the coup. Over a dozen blog sites are putting out information. One site includes daily video clips taken from the nightly TV news and audio clips of news from radio stations. A few bloggers identify themselves, however most remain anonymous. Numerous unchecked comments are being published.

Communications Ltd, who run several private radio stations take their blog site off the air saying that they are increasingly concerned about the nature of the material and that they do not have the resources to manage it.

The army too, becomes increasingly concerned about blogging and say they would close some of the sites down. This proves to be a difficult task and the army make little, or perhaps, no progress.

Journalists phone me and other staff to ask for our views on blogging. I justify blogging as a right but it is hard to feel 'right' when some bloggers fill their sites with racist and defamatory language. One site gets its facts wrong in a big way by declaring a certain chief is dead. A TV journalist (a USP graduate) decides to check the story, and the 'dead' chief answers the phone call! The army is angry-rightfully so.

\section{April 28:}

I hear allegations from student journalists about university students being taken to the army camp, put into cells and threatened. I ask for evidence. Some time later a journalism student tells me that her friend was interrogated at the army barracks. She will talk and be recorded if I keep her name secret. She agrees that I can circulate limited copies of her audio recording to selected people if I agree not to broadcast it. I then have to wait weeks before the student arrives.

\section{May 26:}

She is here. I talk with her before we take out the microphone to record her experience. She recounts that she received an email and then circulated it. It's about an army officer having a sexual affair. 
Observations from my notes on the student interview:

I was at home and soldiers in civilian clothes came to my house. It was around 10-11 pm. My mobile phone was taken. I was then taken to the army camp and put in a cell.

Officer enters my cell with gun. I felt threatened. Officer angry. I was asked if I had an IT background. Student is told that she would be kept in cell for days if she does not reveal contacts. She talks and is then taken to another room.

Asked about her forwarding email? I did do that, she says and then I deleted it, as my USP quota box was full. Officer asks me to phone my relatives to give names. I give my sister's name, phone number and get the password for her computer.

I am then told to go home, and taken in army vehicle. I am picked up next night. Army officer says he wants list of names. I go home.

At the interview I see a list of names with officer. Unsure of where list came from.

Next Monday - they pick me up at $9.30 \mathrm{pm}$. Uncle went with me. Army officer gives threat that my scholarship could be terminated. Sent home. No further action taken.

\section{May 27:}

The intimidation of university students is more common than I had first thought. Another academic says that he too has information on student intimidation by the army. We ask the USP administration to say something publicly on this issue.

\section{May 26-June 1:}

No response from the USP administration. We both agree to write a letter to the newspapers. It is published.

\section{June-July:}

End of semester. Return to New Zealand. Where does this coup go from here?

\section{October:}

The President has asked the Interim Administration, appointed by Bainimarama, to develop a national initiative to Build a Better Fiji for All, through a People's Charter for Change and Progress (PCCP). 


\section{November:}

This idea of a People's Charter is finally on its way. The army says it is going to be developed by people from all walks of life in Fiji-the interim government of course, political parties, the private sector, and NGOs etc. The group will meet early in the next year. A nationwide consultation process will collect views from people all over the country. Bainimarama and Archbishop Petero Mataca will be joint chairpersons for the committee to be called the National Council for Building a Better Fiji (NCBBF).

\section{January 2008:}

John Samy, born in Suva, but now a resident in Auckland, has accepted the position as Head of the Secretariat for the NCBBF. He says former Prime Minister Mahendra Chaudhry [whose cabinet was held hostage in Parliament for 56 days by George Speight and his supporters in an attempted coup in 2000] contacted him about the job. Samy has the task of trying to put together the PCCP by the end of this year. I notice in the communiqué issued by the NCBBF at their first meeting:

...the short timeline envisaged for its completion which is driven by the government's desire to complete the People's Charter prior to the commitment made for the election to be held in March 2009. (NCBBF website, 2008)

The NCBBF consultation is getting off to a difficult start. In a media interview, Samy admits that both the Soqosoqo Duavata ni Lewenivanua (SDL), the party of Laisenia Qarase and also the Methodist Church, are declining to take part on the NCBBF committee. Former Vice-President Ratu Joni Madraiwiwi also declines an informal invitation to be a co-chairperson. Jone Dakuvula joins Samy on the Secretariat of the NCBBF. Dakuvula is noted for being outspoken. During the George Speight coup of 2000, he gave a notable TV interview, which led to an immediate trashing of the Fiji TV studios by angry followers of Speight, who marched from the occupied Parliament to the TV station shouting slogans and firing guns in the air. This led to the declaration of martial law by Bainimarama. 


\section{July 7:}

I accept a four-month contract with the NCBBF to promote public education on the draft People's Charter using media.

\section{July 15-20:}

I am now in Suva. The NCBBF is based in the Parliament Buildings. I walk into their media section and see a notice on the door saying this is the office of the Leader of the Opposition. I talk with staff and read up on what is happening. I hear comments that the media are against the draft of the People's Charter and they publish negative information.

There are three main newspapers in Suva, with The Sun being seen as being the most negative. I recall that its publisher, Russell Hunter, was deported overnight on February 26 for alleged violation of his status. No details were given. And then Evan Hannah, publisher of The Fiji Times, was also deported on May 2. Again no details were given.

Samy is keen to point out that the consultation process on the People's Charter is wholly independent of government or army interference. There are three working groups - one on good governance, one on growing the economy and another on social/cultural identity and nation building. There are also numerous working groups - and the list of their members includes some of the best minds and well-known leaders in Fiji. I notice names-for one, Reverend Akuila Yabaki from the Citizens' Constitutional Forum, a staunch critic of the army coup. Another is Father Kevin Barr who has lived many years in Fiji and has worked and acted on trying to reduce poverty.

\section{July 28:}

The People's Charter aims to make Fiji a better place for all-Fijians, IndoFijians and others. It aims to get rid of the coup culture, which according to Father Kevin Barr is the responsibility of many sections of the population both in Fiji and overseas.

I have tried to point out that we should not place the blame for military coups entirely on the army as though they were the sole agent at work. History shows that the instigators of coups elsewhere (and maybe also in Fiji) have been foreign governments, business interests, traditional elites and a complex mixture of all of the above. (Barr, 2008) 
Most of the elements in the draft of the People's Charter seem to be noncontroversial. There are eleven main points or pillars. These include improving education, improving the health services and the efficiency of the public service. One pillar focuses on reducing poverty. Since the first coup of 1987, poverty has been increasing at the rate of approximately one percent each year. Now, approximately one in three people are living in poverty.

Many of the poor live in appalling squatter zones. Around 100,000 people live in the worst of these settlements, which are between Suva, the capital city and Nausori where the local airport is based. Thirteen percent of the nation now lives in approximately 200 squatter zones. These people have no money to buy or build homes. Many of the squatters settled on the land after paying a few dollars to the landowners. This vakavanua system means that in many cases the landowners have received little money from the squatters, and they too cannot get bank loans to develop their land. Attempts to move squatters are met with a strong resistance, as the question always arises, where do the squatters go?

If this People's Charter is implemented it will allow land to be leased for building, but for a fair rent. The People's Charter process is beginning its public consultation-again! I say again, as the first consultation was taken a while ago. Qarase and others say that people were intimidated during the first round of consultations. Why? One reason was that army and police resources were used to transport many NCBBF people from place to place. Critics say the mere presence of the army and police in uniform is enough to stop people from giving their own opinions.

\section{July 30:}

On reading the draft People's Charter it becomes clear that there is no intention to use it to replace the Constitution. But there are definite intentions to establish a new system of voting in the next general election. The arguments are that the present system is complicated and it leads to a large percentage of invalid votes, up to 12 percent in the last three general elections. Another argument is that the present system lacks legitimacy, as there is no correspondence between the total votes for a political party and the number of seats it gets in Parliament. It quotes the example of 40 percent of the indigenous Fiji population living in rural areas that elect 17 members, while the majority of indigenous Fijians residing in urban areas elect only six members. 
One political party that got 14 percent of first preference votes in 1999 , 10 percent in 2001 and 6 percent in 2006 did not gain a single seat in any of these three general elections.

The new voting system proposes a party list system with each voter having one vote for one candidate. Seats are to be allocated on a proportional system according to the total constituency vote. So, if party 'A' gets 60 percent of a constituency vote it gets 60 percent of the seats.

All communal seats are to be abolished which means that anyone who is eligible to vote can stand for Parliament. It's being argued that this will favour women and small minorities. Citizens over the age of 18 would be eligible to vote. This would add around 30,000 more people to the electoral roll.

\section{August:}

There is talk among the NCBBF members about consultation and respect for all, but the public arguments are bitter. I notice the NCBBF Secretariat frequently buys a whole page of a newspaper to advertise its opinions. It believes that the main media-mainly the newspapers-are biased in their reporting of NCBBF matters.

The Methodist Church has come out against the draft of the People's Charter and told its members not to sign any documents supporting it. There are around 300,000 Methodists in Fiji. There are also confirmed reports of various chiefs telling their people not to vote for the draft charter. So much for democracy!

The Secretariat of the NCBBF has contacted the Methodist church leaders and sent some copies of the draft People's Charter for them to read, discuss and hopefully distribute to members. The boxes were returned unopened and unread. All this to and fro between the NCBBF and the Methodist Church has been seen on the TV news.

The NCBBF Secretariat devised a slogan, 'Be informed, be involved', and produced a flyer answering questions about the draft People's Charter. In the title it says, 'the myths versus the truth'.

Myths identified as being wide-spread include: the People's Charter will replace the Constitution; that the Charter is illegal; that it will take away the identity of the indigenous Fijian people and also their land; that the military will become custodians of the charter. Copies of this sheet are given to the NCBBF members who talk at public meetings about the People's Charter. 
A vast number of copies of the draft People's Charter are printed, I believe around_200,000 copies. They are in the three main languages-English, Hindi and Fijian. This is a significant development. The present Constitution was never printed or circulated in such large numbers or in the three languages. I watch each day as dozens of boxes arrive from the printer, are unloaded and then later reloaded on different vehicles for distribution around the country.

A response form has also been printed for signing by the population. It's simple - you say, yeah or nay to the ideas in the draft People's Charter and if you want to comment, you can do so. John Samy is hoping for a large public response to the form. There is talk of getting an 80 percent, but that view is being amended. The NCBBF say it is not a referendum form, just a response form indicating the viewpoint of the people who sign it. To ensure its validity the NCBBF Secretariate is asking people who sign to give their names and address. And every form has an individual number, to prevent fraud, i.e. photocopying.

To help galvanise the population to know about the content of the People's Charter, local radio is being used. At least six radio stations covering the country are being paid to broadcast short messages each day on where public meetings about the draft charter are to be held. Other radio messages outline key points on the draft of the charter. The new Fiji private TV station is running several discussions on the draft People's Charter.

\section{September:}

The public consultation process is in full swing. Members of the NCBBF, the Secretariat and staff from government district offices are travelling around villages, and towns talking about the contents of the People's Charter. Public forums are planned. The Interim Prime Minister. Commodore Bainimarama is being invited as the chief guest to a large outdoor meeting in Lautoka. Around 3000 people attend this meeting.

The amount of flak being generated by the draft People's Charter appears widespread. At least once a week there is a full-page article in one of the newspapers that expresses the point of view that a general election must be held by March 2009-so that democracy is restored. Qarase is quoted again and again as supporting this viewpoint and he attacks the draft of the People's Charter.

But there is also a strong support for the charter concept. A lengthy statement, called 'Why the SDL party needs to change its approach and 
its leadership for Fiji to go forward', is signed by two NCBBF members, Ratu Meli Vesikula and Adi Finau Tabakaucoro (2008), and sent out as a media release. The gutsy comments in this statement accuse former Prime Minister Qarase of having no mandate to govern after the 2000 coup.

... his Interim Government in 2000 had no legal mandate from anybody to remain in office after the Court ruled them illegal, let alone form a political party. When Ratu Mara headed an Interim government after 1987, those ministers who wanted to form political parties or contest the election had to resign. But not Qarase and his interim government. They illegally extended their term as interim government."

In the same article the writers talk of Qarase and alleged corruption.

The Auditor General's Report shows that they illegally spent $\$ 20$ million of public funds to get elected in 2001 under the "Agricultural Affirmative Action Assistance Scheme.

At the time of reading this media release, I check an opinion from another source, University of Waikato senior lecturer Dr David Neilson. He says there was evidence of deliberate and explicit vote buying by the SDL close to the 2006 election-polling day.

The New Zealand government continues to take the view that the SDL Party was democratically elected to government in a free and fair election. The evidence presented in the submissions and in the inquiry's report calls this view into question. (Neilson, 2007)

These opinions of fraud at the general elections seem to be widespread. Dr Brij Lal, one of the architects of the 1997 Constitution, in an article presented to the Round Table in London and reported in The Fiji Times writes about an agricultural scam during the 2001 general election campaign. It involved millions of dollars that Qarase and his supporters used to buy votes under the guise of Fijian affirmative action.

\section{October 9:}

What an eventful morning. At the NCBBF Secretariat, many of the senior staff sat glued to the television watching a live broadcast as the Acting Chief 
Justice laboriously reads the two-hour judgement called 'Qarase and Others v Bainimarama and Others'. The judge makes references to the Magna Carta, decisions taken in colonial controlled India, the Second World War in Burma (Myanmar) and modern Malawi... then the Bainimarama coup is declared legal.

It was difficult and still is, for this writer to reconcile the measured judgment of the court with the first days of the coup where the images of soldiers with guns controlling the streets. A Prime Minister was sent packing back to his island. There was intimidation suffered by some citizens and practising journalists. A newspaper editor and publisher were deported and no specific reasons given for this action by the interim government.

As the judgment settles in my mind, I recall that Chief Justice Daniel Fatiaki is under suspension for so-called illegal activities. He is still under suspension on full pay. Under normal circumstances he would have heard the case brought by Qarase. So why has the State not proceeded with a court case against him?

\section{November 12:}

Now-just over a month after this disturbing judgement, comes the bombshell that Chief Justice Fatiaki is to retire (Fiji Sun, 12 November 2008) with a huge financial settlement. All allegations against him have vanished. The interim Attorney General gives a cryptic comment that:

The Chief Justice has retired. The lawyers in Australia and New Zealand have nothing to do with the retired chief justice.

But the State is not to get away so easily with this with this sort of ambiguous and imprecise viewpoint. The Fiji Law Society president, Dorsami Naidu, goes public, describing the whole process as a waste of taxpayer's money and says that the State had originally mentioned that it had a strong case against the Chief Justice and therefore they should have proceeded with it. There are questions in my mind-but now the Chief Justice has 'retired'.

\section{December 12:}

The draft of the People's Charter has been endorsed by the President (Fiji Sun, 12 December 2008) with more than 60 percent of the population over the age of 18 expressing support for it. 


\section{December 20:}

Another eventful morning. The Acting Chief Justice, Anthony Gates, is confirmed as Chief Justice.

\section{December 22:}

Radio New Zealand International interviews the Fiji Law Society's president, Dorsami Naidu, quoting him saying that the appointment of Anthony Gates as Chief Justice is unlawful.

Why do they shout from their rooftops that the Constitution is in place when they have cannibalised the Constitution as it were and any appointment made by this regime is unlawful. They can make these appointments because they are in effective control of the country, but let's not hide behind the facade. (RNZI, 22 December 2008)

\section{January 21, 2009:}

It's time to have a look back at this diary and reflect on the 5 December 2006 coup and its aftermath.

It's clear that the army is still in full control two years later. The military regime that kicked out former Prime Minister Qarase at the point of a gun outmaneuvered him and his supporters through the court judgment of 9 October 2008.

Bainimarama has also made it clear that he will decide when the next general election will take place. To his credit, the national census has been conducted and this process was essential if a fair election was to be held. The last national census figures were taken in 1996. Fiji's new Supervisor of Elections, Felicity Heffernan has been appointed. There are conflicting reports about how long it will take to set up all the procedures for a general election - a year is considered a reasonable time by some critics.

Bainimarama says he respects the Constitution of Fiji and that the People's Charter will be adopted by his government as a vision statement, but that he wants a reform of the electoral system before the general election can take place. So how does he go about implementing that electoral process? The start is through a special President's Political Forums in April 2009 where different political parties are being invited to take part. A preliminary meeting was held last year. More substantial meetings are due this year, leading, we hope to the process of political action. 
The People's Charter is nearly complete. There are going to be a few amendments, and queries. What will the people of Fiji be called-long a contentious issue as the term Fijian has traditionally meant indigenous Fiji islander? But it looks as if the draft of the People's Charter has received an overwhelming vote of confidence from the people. Only four percent of the respondents did not approve of the charter.

So will Fiji have a better future? The general election still appears to be a substantial distance away; Fiji politicians still have many disagreements among themselves. Australia and New Zealand talk about moving the general election process forward, but how will they help the return to democracy? Their rhetoric is high and politically correct but some new thoughts and processes are going to be needed to influence Bainimarama, as he has already kicked out two New Zealand diplomats

The relationship between the media and the army has hit another low. The High Court in Suva has fined The Fiji Times F\$100,000 for contempt of court, not for something an editor or journalist had written, but for a letter they had published, criticising the Qarase v Bainimarama court case. The newspaper issued a public apology two weeks later, but this was not enough for Aiyaz Sayed-Khaiyum, the interim Attorney General who suggested that the court impose a stronger penalty. Why should he want a stronger penalty?

Ironically another newspaper, the Fiji Daily Post published the same letter, but the authorities did not find out about it until a considerable time later. When they did, they began proceedings and the case is scheduled for an April hearing.

The NCBBF was critical of the media during the period of time it worked on the draft of the People's Charter. It recommended changes to the law to set up a Media Tribunal which is also planned to be seen as an organisation to train qualified local personnel for editorial, subeditorial and publisher positions; to provide a wide diversity of local programmes for television media and to develop community radio and community television through a media tax.

I have found myself looking back again and again at what has happened in the last 39 years of Fiji's post-colonial history. Four coups-increasing poverty - a steadily failing relationship with neighbours Australia and New Zealand and now the European community.

Who, I ask myself, is taking responsibility for this spiritual and economic decay in Fiji? The most interesting answer comes not from the coup leaders, 
but from President Ratu Josefa Iloilo. A week before Christmas 2008, he gave a significant speech when he spoke to the Fijian chiefs at the army barracks in Suva.

He said that the indigenous people must realise that they have not been led well for more than 60 years, as many of the chiefs have been self-serving and oblivious to the people's needs. The President used a metaphor for the nation, saying:

The oar is broken. There is a need to use the mast as an oar. That is the challenge to which we must rise. (Fiji Times Online, 18 December 2008)

As for the media-The Fiji Times has been keelhauled on this ship by the Fiji $\$ 100,000$ fine for contempt of court, plus a three month imprisonment sentence for the editor which has been suspended for two years. (Fiji Times, 23 January 2009)

On the positive side - the draft of the People's Charter has been largely accepted by the population as the way forward. Now some methodology must be found for it to be incorporated either into the Constitution or the political system. That may take all this year and next. So when will the next general election take place?

\section{April 20, 2009}

I've stopped keeping my diary for a while as I've been away from Fiji since November 2008 and it is also getting harder to get accurate information out of the country. In the last weeks I have begun self-censoring my own email to my mates in Suva, as I wonder if they are being monitored by their minders.

The normally trustworthy websites of The Fiji Times newspaper and Fijlive are no longer fully 'reliable' as they have had to buckle under the martial law rules of the leader and to report only 'good news'. So, each day I look at the numerous blog sites. Some make me shudder, like the Rawfijinews blogsite of April 19, which carried an item with the title 'The judiciary under Adolf Sayed Khaiyum-Hitler re-visited'. I blame the commodore for the blog site bog he is making media walk through. 


\section{Final diary note, April 24:}

Today Prime Minister, you were invested with an award by the President for 'eminent achievement and merit of highest degree and service to Fiji and to humanity at large'. It's a big gift and at the moment I don't think you have earned it. That time may come - I don't know? I guess 2014 is the date! At some time you will have to talk seriously with Australia and New Zealand. Our present government cannot publicly support you and also avoid the criticism from within New Zealand and on the international scene. I hope though, that John Key, and you too, Prime Minister, agree to find a way to develop contacts between New Zealand and Fiji to help you on your path to democracy. I know the contacts will have to be secret and that is OK. You need help with accountants to investigate the corruption you despise and lawyers and police to help prepare court cases. And when the elections do take place, I hope that these secret contacts from my country and your country will have helped you on the way to realise your dreams of a better Fiji for all. That will be merit of the highest degree.

\section{Chronology}

1987, April 12: Dr Timoci Bavadra's Fiji Labour Party wins general election 1987, May 14 and September 26: Colonel Sitiveni Rabuka leads two coups.

1997, July 25: Multiracial Constitution promulgated.

1999, May 19: First Indo-Fijian PM sworn in. Mahendra Chaudhry, who heads a multiracial government led by the Fijian Labour Party, which won a landslide victory at the polls - the first under the new constitution.

2000, May 19: Failed businessman George Speight stages attempted coup, seizes Parliament and takes Chaudhry government hostage for 56 days

2000, May 29: Commodore Voreqe Bainimarama declares martial law and ousts President Ratu Sir Kamisese Mara.

2000, July 3: Bainimarama appoints banker Laisenia Qarase as caretaker prime minister.

2000, July 27: Military follow the Muanikau Accord by arresting Speight and key coup leaders.

2000, November 2: Elite counter-revolutionary soldiers mutiny at the Queen Elizabeth Barracks in Suva and stage an assassination attempt on the life Bainimarama.

2002, February 18: Speight convicted of treason and sentenced to death-commuted to life imprisonment within hours

2006, December 5: After months of warnings, Bainimarama stages a coup and ousts Qarase from office.

2008, October 9: High Court judgment declares interim regime legal. 2009, April 9: Three Australian Court of Appeal judges declare regime illegal. 
2009, 10 April: President Josefa Iloilo appoints himself as Head of State, abrogates the Constitution, dismisses judiciary, postpones elections until 2014, reappoints Bainimarama and issues decrees restricting media freedom. Four days later, the military regime expels three foreign journalists.

\section{References}

Barr, K. (2008). Fiji's coup culture. Paper presented in the State of the Nation and Economy Report, August 2008.

Craddock, P. (2009, April 14). Repressive Fiji regime forces return to 'news by blog'. Café Pacific. Retrieved on 19 April 2009, from http://cafepacific.blogspot. com/2009/04/repressive-regime-gag-ushers-in-return.html

Fiji Sun (2008, December 24). Charter ready to be implemented.

Fiji Sun (2008, November 12) AG clears the air on Fatiaki's payout. Retrieved on 23 January 2009, from www.sun.com.fj/main_page/view.asp?id=11091

Fijivillage.com (2009, January 23). Fiji's interim attorney-general says court case justified. Retrieved on 23 January 2009, from www.fijivillage.com/?mod=story\& $\mathrm{id}=23010904 \mathrm{bdbf} 4 \mathrm{a} 47 \mathrm{~b} 771167 \mathrm{bf} 387 \mathrm{~d} 5$

Lal, B. (2007a). Anxiety, uncertainty, and fear in our land. Fiji's road to military coup, 2006. The Round Table, 96(389): 135-53. Retrieved on 23 January 2009, from www.fijilive.com/archive/showpdf.php?pdf

Lal, B. (2007b). This process of political readjustment. Aftermath of the 2006 Fiji coup. Retrieved on 23 January 2009, from www.fijilive.com/archive/showpdf. php?pdf=2007/07/2006coup_aftermath.pdf

Moore, P. (2008, August 19). Media and the people's charter. A media release from the NCBBF.

NCBBF. (2008). First meeting of NCBBF Communiqué. Retrieved on 23 January 2009, from www.fijipeoplescharter.com.fj/

NCBBF. (2008, August 26). Remarks at the launching of the draft peoples charter, public outreach and consultations. Retrieved on 23 January 2009, from www.fijipeoples charter.com.fj/pr19.htm

Neilson, D. (2007). Fiji elections dogged by deficiencies. Retrieved on 23 January 2009, from www.waikato.ac.nz/news/index.shtm? $=645$

Ratuva, S. (2007). Coup and regime change in Fiji. Retrieved on 23 January 2009, from www.fijitimes.com/story.aspx/id=5491

Rika, N. (2007). Fiji: Journalists describe intimidation by government. Retrieved on 23 January, from www.pmw.c2o.org/2007/fiji5188.html

RNZI. (2008, December 22). Fiji's interim regime's accused of illegally appointing new Chief Justice. Retrieved on 23 January 2009, from www.rnzi.com/pages/ news.php?op=read\&id $=43853$

The Fiji Times ( 2009, January 22). Fiji Times fined. Retrieved on 22 January 2009, from www.fijitimes.com/story.aspx?id=112549

The Fiji Times (2008, December 18). Time to change tack. Retrieved on 22 January 2009, from www.fijitimes.com/story.aspx?item=leader 
Vesikula, M., and Tabakaucoro, F. (2008). Why the SDL party needs to change its approach and its leadership for Fiji to go forward. NCBBF.

Vesikula, M., and Tabakaucoro, F. (2008, September). Why the indigenous Fijians should support the draft peoples charter. Retrieved on 23 January 2009, from: http://www.fijipeoplescharter.com.fj/i-taukei.pdf

Patrick Craddock is a media educator and journalist who worked at Radio New Zealand for more than 20 years and at the University of the South Pacific from 1991 until 2000, as a radio and multimedia producer. After the George Speight coup occurred he went to Mozambique for three years as a media project manager. Craddock was then broadcast journalism lecturer at the University of the South Pacific from 2005 until after the 2006 coup. He later returned to Fiji as social media educator for the National Council for Building a Better Fiji (NCBBF).

pcqmol@actrix.co.nz

\title{
(9) Waiariki
}

Journalism Educators Association of New Zealand conference 'Walking the Talk'

Workshops and papers are invited from all those who teach, lecture and develop resources for the education of journalists in Aotearoa/New Zealand and around the world.

\author{
December 3-4, 2009 \\ in Rotorua and hosted by \\ Waiariki Institute of Technology \\ More details on www.jeanz.org.nz
}

